\title{
SURVEI PERILAKU PENCEGAHAN COVID-19 PADA IBU MAHASISWA NERS STIKes SANTA ELISABETH MEDAN
}

\author{
Lindawati Simorangkir ${ }^{1}$, Ice Septriani Saragih ${ }^{2}$, Mardiati Barus ${ }^{3}$, David Sumanto Napitupulu ${ }^{4}$ \\ ${ }_{1,2,3}$ Prodi Ners, STIKes Santa Elisabeth Medan \\ ${ }^{4}$ Prodi Teknologi Labotarium Medik, STIKes Santa Elisabeth Medan \\ Email: ${ }^{1}$ lindasimorangkir79@gmail.com, ${ }^{2}$ iceseptriani.saragih@gmail.com,

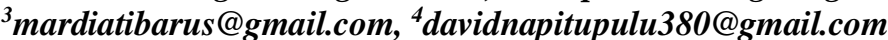

\begin{abstract}
ABSTRAK
COVID-19 dikategorikan sebagai penyakit menular. Penambahan jumlah kasus COVID-19 berlangsung cukup cepat dan terjadi penyebaran yang sangat pesat. Tujuan penelitian ini adalah untuk mengetahui survei perilaku pencegahan COVID-19 pada keluarga mahasiswa ners STIKes Santa Elisabeth Medan. Rancangan penelitian adalah deskriptif dengan metode cross sectional. Populasi dalam penelitian ini yakni ibu mahasiswa program studi Ners tingkat 2 STIKes Santa Elisabeth Medan yang berjumlah 84 ibu mahasiswa. Tehniknya menggunakan teknik total sampling dengan jumlah sampel penelitian 84 responden. Pengumpulan data peneliti menggunakan google form berupa kuesioner yang terdiri dari 16 pernyataan tentang perilaku pencegahan COVID-19. Hasil penelitian adalah mayoritas perilaku responden selalu menggunakan masker saat keluar rumah, sebanyak 72,6\%. Sebagian besar perilaku responden selalu mencuci tangan dengan menggunakan sabun sebanyak 47,6\%. Sebagian besar perilaku responden selalu menjaga jarak sebanyak 52,4\%. Sebagian besar perilaku responden selalu menggunakan hand sanitizer sebanyak 51,2\%. Sebagian besar perilaku responden selalu membersihkan rumah sebanyak $82,1 \%$. Sebagian besar perilaku responden selalu melakukan aktivitas di rumah saja sebanyak 32,1\%. Meningkatkan kesadaran masyarakat dan mampu dalam melakukan pencegahan COVID-19 melalui komunikasi dan edukasi.
\end{abstract}

Kata kunci: Perilaku, Pencegahan Covid-19, Keluarga.

\section{ABSTRACT}

COVID-19 is categorized as an infectious disease. The increase in the number of COVID-19 cases took place quite quickly and there was a very rapid spread. The purpose of this study was to find out a survey of COVID-19 prevention behavior in the families of STIKes Santa Elisabeth Medan nurse students. The research design is descriptive with the Cross Sectional method. The population in this study were the mothers of students of the Nursing program level 2 STIKes Santa Elisabeth Medan, amounting to 84 student mothers. The technique uses the total sampling technique with a total sample of 84 respondents. The researcher collected data using a google form in the form of a questionnaire consisting of 16 statements about COVID-19 prevention behavior. The result of the research is that the majority of respondents' behavior always uses a mask when leaving the house, as much as $72.6 \%$. Most of the respondents' behavior is always washing hands with soap as much as 47.6\%. Most of the behavior of respondents always keep a distance as much as 52.4\%. Most of the behavior of respondents always use hand sanitizer as much as $51.2 \%$. Most of the respondents' behavior is always cleaning the house as much as $82.1 \%$. Most of the respondents' behavior is always doing activities at home as much as $32.1 \%$. Increasing public awareness and being able to prevent COVID-19 through communication and education

Keywords: Behavior, Covid-19 Prevention, Family.

\section{PENDAHULUAN}

COVID-19 dikategorikan sebagai penyakit menular. Penyebaran penyakit ini dimulai di Wuhan, provinsi Hubei. Persentasi kejadian COVID-19 di Wuhan, China dilaporkan ada 96.000 kasus dan sebanyak 3.300 kasus dilaporkan positif COVID-19 mengalami kematian (Singhal, 2020). Berdasarkan hasil review yang dilakukan oleh (Kakodkar et al., 2020) menemukan bahwa pada bulan Maret terdapat 304.900 kasus dimana sebanyak 94,93 telah diobati dan 13.001 kasus meninggal dimana pada kasus ini dapat diinterpretasikan bahwa COVID-19 dapat menyebar kepada dua atau tiga orang yang baru. Penambahan jumlah kasus COVID-19 berlangsung cukup cepat dan terjadi penyebaran baik di Wuhan maupun diluar wilayah Wuhan.

Sampai dengan 16 Februari 2020, dilaporkan jumlah kasus adalah 51.857 dengan konfirmasi kematian 1.669 di 25 
negara (WHO, 2020). Virus ini telah menyebar ke Indonesia. Pemerintah mensosialisasikan pencegahan dengan menerapkan pola hidup sehat dan kebijakan Work From Home dalam 14 hari untuk mengurangi penyebaran COVID-19 (Nurhalimah, 2020). Virus ini ditransmisikan melalui inhalasi atau kontak dengan droplet orang yang terinfeksi COVID-19 dengan masa inkubasinya adala 2-14 hari.

Gejala yang pada umumnya terjadi pada orang yang terinfeksi adalah demam, batuk, sakit tenggorokan, napas pendek, kelelahan dan pada beberapa orang diantaranya mengalami nyeri otot (Singhal, 2020). Saat ini, pengobatan COVID-19 adalah dengan terapi suportif (Huang et al., 2020). Salah satu memutus mata rantai penularan COVID19 adalah melakukan pencegahan yakni untuk tetap dirumah, menjaga jarak dan menghindari kerumunan. Selain itu kita harus tetap melakukan perilaku hidup bersih, meningkatkan daya tahan tubuh serta menggunakan masker.

Hasil wawancara kepada 8 orang mahasiswa Ners Tingkat 2 didapat data bahwa 5 mahasiswa mengatakan bahwa selama di rumah mereka sering keluar rumah tanpa menggunakan masker dikarenakan dikampung belum ada data yang dilaporkan terkena sakit covid, ditempat tinggal mereka sering melihat sering ada pesta dan orang yang hadir pesta tidak menggunakan masker 2 mahasiswa mengatakan di rumah tidak menyediakan tempat mencuci tangan dan sabun, jika mau cuci tangan ke kamar mandi. Mereka juga jarang melakukan olah raga, jika ya diajak teman untuk main bola kaki. 1 mahasiswa mengatakan selalu menggunakan masker jika keluar dari rumah, selalu membawa hand sanitizer dan setiap pagi jalan santai sambil berjemur.

Keluarga merupakan sistem dasar tempat dilakukan dan dijalankan perilaku dan perawatan kesehatan. Keluarga juga merupakan unit terkecil dari masyarakat dimana dalam satu keluarga terdiri dari berbagai macam usia. COVID-19 dapat menyerang segala usia (Singhal, 2020) oleh karena itu langkah dasar dalam memutus rantai penularan COVID-19 bisa dimulai dari unit terkecil yaitu keluarga. Berdasarkan permasalahan diatas, maka peneliti tertarik untuk melakukan penelitian tentang mengetahui survei perilaku pencegahan
COVID-19 Keluarga Mahasiswa Ners STIKes Santa Elisabeth Medan.

\section{METODE}

Rancangan penelitian yang digunakan peneliti adalah Deskriptif dengan metode Cross Sectional. Populasi dalam penelitian ini yakni seluruh ibu mahasiswa Prodi Ners tingkat 2 STIKes Santa Elisabeth Medan berjumlah 84 orang

Pengambilan sampel dalam penelitian dengan teknik Total sampling dengan jumlah sampel 84 ibu mahasiswa. Penelitian ini telah dilaksanakan pada bulan Maret 2021. Pada pengumpulan data peneliti menggunakan google form berupa kuesioner yang terdiri dari 16 pernyataan.

Telah dilakukan uji validitas dan reliabilitas pada Program studi TLM (Teknologi Laboratorium Medik) sebanyak 30 responden. Analisis dalam penelitian ini analisis univariat yakni melihat distibusi frekuensi perilaku pencegahan COVID-19 dengan nilai valid 0,472 , dan nilai koefisien alpha 0,720 .

\section{HASIL DAN PEMBAHASAN}

\subsection{Hasil}

\section{Distribusi Frekuensi Karakteristik Responden}

Distribusi frekuensi karakteristik responden berdasarkan hasil pengambilan data yang dilakukan kepada 84 responden berdasarkan karakteristik meliputi pendidikan, pekerjaan, jumlah anggota keluarga dan tempat tinggal. Distribusi karakterisitik dapat dilihat pada tabel 1: 


\begin{tabular}{|c|c|c|c|}
\hline No & Karakteristik & Jumlah & $\%$ \\
\hline \multirow[t]{7}{*}{1} & Pendidikan & & \\
\hline & $\cdot \mathrm{SMP}$ & 5 & 6,0 \\
\hline & - SMA & 25 & 29,7 \\
\hline & · Diploma & 4 & 4,8 \\
\hline & - Sarjana & 48 & 57,1 \\
\hline & - Magister & 2 & 2,4 \\
\hline & - Doktor & 0 & 0 \\
\hline \multirow[t]{4}{*}{2} & Pekerjaan & & \\
\hline & - tidak bekerja & 37 & 44 \\
\hline & - swasta & 23 & 27,4 \\
\hline & - PNS & 24 & 28,6 \\
\hline \multirow[t]{5}{*}{3} & Jumlah & & \\
\hline & keluarga & & \\
\hline & - 2 orang & 2 & 2,3 \\
\hline & - 3 orang & 10 & 12,0 \\
\hline & $\cdot>4$ orang & 72 & 85,7 \\
\hline \multirow[t]{9}{*}{4} & Tempat tinggal & & \\
\hline & $\cdot$ Medan & 13 & 15,4 \\
\hline & $\cdot$ Karo & 5 & 6,0 \\
\hline & $\cdot$ Nias & 1 & 17,9 \\
\hline & - Tebing Tinggi & & 0 \\
\hline & - P. Siantar & 3 & 3,6 \\
\hline & · Pekanbaru & 8 & 9,5 \\
\hline & - Toba & 3 & 3,6 \\
\hline & $\cdot$ Dll & 37 & 44,0 \\
\hline
\end{tabular}

Berdasarkan tabel 1 karateristik responden dapat disimpulkan sebagian besar tingkat pendidikan adalah sarjana $(57,1 \%)$, berdasarkan pekerjaan, sebagian besar responden tidak bekerja (44\%), berdasarkan jumlah anggota keluarga, responden sebagian besar adalah keluarga besar karena 85,7\% memiliki lebih dari 4 orang. Dan berdasarkan tempat tinggal, sebagian besar responden berada diluar dari Medan, Karo, Nias, Tebing Tinggi, Pematang Siantar, Pekanbaru dan Toba.

Tabel 2. Distribusi Frekuensi Perilaku Menggunakan Masker $(\mathrm{n}=84)$

\begin{tabular}{clcc}
\hline No & Kategori Perilaku & Jumlah & $\mathbf{\%}$ \\
\hline 1 & Tidak pernah & 0 & 0 \\
\hline 2 & Kadang - kadang & 8 & 9,6 \\
\hline 3 & Sering & 15 & 17,8 \\
\hline 4 & Selalu & 61 & 72,6 \\
\hline & Jumlah & $\mathbf{8 4}$ & $\mathbf{1 0 0}$ \\
\hline Berdasarkan tabel & 2 & Perilaku
\end{tabular}
menggunakan masker saat keluar rumah, sebanyak $72,6 \%$ responden menjawab selalu menggunakan masker. Dalam hal ini, responden sebagian besar patuh kepada protokol kesehatan dan tidak ada yang tidak pernah menggunakan masker.
Tabel 3. Distribusi Frekuensi Perilaku Mencuci Tangan dengan Sabun $(\mathrm{n}=84)$

\begin{tabular}{clcc}
\hline No & Kategori Perilaku & Jumlah & $\mathbf{\%}$ \\
\hline 1 & Tidak pernah & 1 & 1,2 \\
\hline 2 & Kadang - kadang & 25 & 29,8 \\
\hline 3 & Sering & 18 & 21,4 \\
\hline 4 & Selalu & 40 & 47,6 \\
\hline & Jumlah & $\mathbf{8 4}$ & $\mathbf{1 0 0}$
\end{tabular}

Berdasarkan tabel 3 perilaku mencuci tangan dengan sabun, sebanyak 47,6\% responden menjawab responden selalu mencuci tangan dengan menggunakansabun dan sebanyak $21,4 \%$ responden yang sering mencuci tangannya dengan sabun. artinya, secara umum kebiasaan mencuci tangan dengan menggunakan sabun sudah dilakukan, hanya saja cuma $1,2 \%$ saja yang tidak pernah mencuci tangan dengan menggunakan sabun.

Tabel 4. Distribusi Frekuensi Perilaku Menjaga Jarak $(n=84)$

\begin{tabular}{clcc}
\hline No & Kategori Perilaku & Jumlah & \% \\
\hline 1 & Tidak pernah & 0 & 0 \\
\hline 2 & Kadang - kadang & 15 & 17,8 \\
\hline 3 & Sering & 25 & 29,8 \\
\hline 4 & Selalu & 44 & 52,4 \\
\hline & Jumlah & $\mathbf{8 4}$ & $\mathbf{1 0 0}$ \\
\hline
\end{tabular}

Berdasarkan tabel 4 perilaku menjaga jarak, sebanyak 52,4\% responden selalu melakukan jaga jarak dan tidak ditemukan yang tidak pernah melakukan jaga jarak. Hal ini menggambarkan responden sudah baik dalam melakukan jaga jarak.

Tabel 5. Distribusi Frekuensi Perilaku Menggunakan Hand Sanitizer $(\mathrm{n}=84)$

\begin{tabular}{clcc}
\hline No & Kategori Perilaku & Jumlah & $\mathbf{\%}$ \\
\hline 1 & Tidak pernah & 6 & 7,2 \\
\hline 2 & Kadang - kadang & 19 & 22,6 \\
\hline 3 & Sering & 16 & 19,0 \\
\hline 4 & Selalu & 43 & 51,2 \\
\hline & Jumlah & $\mathbf{8 4}$ & $\mathbf{1 0 0}$ \\
\hline Berdasarkan tabel & 5 & perilaku
\end{tabular}
menggunakan hand sanitizer, sebanyak $51,2 \%$ responden selalu menggunakan hand sanitizer dan hanya sedikit yang ditemukan responden yang tidak pernah menggunakan handsanitizer, yaitu 7,2\%. Hal ini menggambarkan responden sudah peduli akan pentingnya hand sanitizer saat keluar rumah. 
Tabel 6. Distribusi Frekuensi Perilaku Membersihkan Rumah ( $\mathrm{n}=84$ )

\begin{tabular}{clcc}
\hline No & Kategori Perilaku & Jumlah & $\mathbf{\%}$ \\
\hline 1 & Tidak pernah & 0 & 0 \\
\hline 2 & Kadang - kadang & 3 & 3,6 \\
\hline 3 & Sering & 12 & 14,3 \\
\hline 4 & Selalu & 69 & 82,1 \\
\hline & Jumlah & $\mathbf{8 4}$ & $\mathbf{1 0 0}$ \\
\hline Berdasarkan tabel & 6 & Perilaku
\end{tabular}

membersihkan rumah, sebanyak $82,1 \%$ responden selalu membersihkan rumah dan ditemukan $0 \%$ yang tidak pernah membersihkan rumah. Hal ini menunjukkan responden sudah peduli akan pentingnya kebersihan rumah.

Tabel 7. Distribusi Frekuensi Perilaku Melakukan Aktivitas di Rumah Saja $(\mathrm{n}=84)$

\begin{tabular}{clcc}
\hline No & Kategori Perilaku & Jumlah & \% \\
\hline 1 & Tidak pernah & 1 & 1,2 \\
\hline 2 & Kadang - kadang & 30 & 35,8 \\
\hline 3 & Sering & 26 & 30,9 \\
\hline 4 & Selalu & 27 & 32,1 \\
\hline & Jumlah & 84 & 100 \\
\hline
\end{tabular}

Berdasarkan tabel 7 Perilaku melakukan aktivitas di rumah saja, sebanyak 32,1\% responden selalu melakukan aktivitas di rumah dan ditemukan $1,2 \%$ yang tidak pernah melakuk anaktivitas di rumah. Hal ini menunjukkan responden sebagian besar melakukan aktivitas di rumah namun sebagian kecil di luar rumah.

\subsection{Pembahasan}

Hasil analisis data menunjukkan bahwa sebagian pendidikan responden adalah pendidikan sarjana sebanyak $57,1 \%$ diikuti dengan pendidikan SMA sebanyak 29,7\%. Berdasarkan karakteristik pekerjaan sebagian besar responden tidak bekerja sebanyak $44 \%$.

Tingkat pendidikan merupakan salah satu faktor yang dapat berpengaruh ke perilaku sehat, dimana semakin tinggi tingkat pendidikan maka individu tersebut akan memiliki kematangan khususnya melakukan pencegahan dan kesadaran dalam melakukan protokol kesehatan. Hal ini diperjelas oleh (Taufiq et al., 2013) yang mengatakan bahwa pendidikan sebagai suatu proses dalam rangkaian yang akan mempengaruhi dan menimbulkan perubahan perilaku pada dirinya, karena semakin tinggi tingkat pendidikan seseorang semakin mudah mereka menerima informasi kesehatan. Terkhusus responden yang sedang diteliti ini dominan sudah sarjana, jadi untuk penerapan protokol kesehatan ditengah-tengah keluarga pasti dilakukan dengan baik.

Penggunaan masker menjadi suatu kebijakan yang paling mungkin karena secara kasat mata kita tidak bisa memprediksi siapa dan dimana virus dapat ditularkan (Kimball et al., 2020). Saat ini masker sudah menjadi salah satu APD (Alat Pelindung Diri). Setiap keluarga pastinya sudah menyediakan masker dengan jumah yang banyak. Berdasarkan hasil kuesioner ini, tidak ditemukan responden yang tidak menggunakan masker di luar rumah, dengan persentase sebesar $0 \%$. Dalam hal ini, setiap responden sudah paham betul akan manfaat dari masker tersebut.

Tangan adalah pusat masuknya kuman penyakit kedalam tubuh, mulai saat bersalaman, memegang pintu kamar kecil/toilet, menyentuh benda yang ada kuman, sehabis BAK atau BAB serta menyentuh segala sesuatu yang disentuh orang seperti memegang uang dan sebagainya. Tangan yang kelihatan bersih belum tentu dapat tercegah dari penyakit infeksi. Apalagi tangan yang bersentuhan langsung dengan kotoran manusia, binatang, cairan tubuh, makanan atau minuman yang terkontaminasi saat tidak dicuci dengan sabun dapat memindahkan bakteri, virus dan parasit kepada orang lain (Apriany, 2012).

Covid-19 mengubah cara pandang masyarakat untuk memulai kelaziman baru dengan rutin mencuci tangan. Hal tersebut telah diatur dalam peraturan Kemenkes Nomor 3 Tahun 2014. Dalam satu pilar yang tertuang didalam adalah gerakan untuk mencuci tangan dengan menggunakan sabun. Pasal 3 ayat 2 juga menyebutkan bahwa mencuci tangan minimal dapat terwujud melalui kegiatan membudayakan perilaku cuci tangan dengan manggunakan air bersih secara kontinu.

Jika dilihat dari hasil kuesioner ini, ada sebesar 47,6\% responden yang selalu mencuci tangan saat di luar rumah. Dan sebanyak 21,4\% responden yang sering mencuci tangan saat di luar rumah. Dapat disimpukan bahwa responden secara umum sudah menyadari akan pentingnya kebiasaan mencuci tangan dengan sabun. Pemerintah menekankan pentingnya dalam menjaga jarak untuk mencegah penularan penyakit (Kementerian Kesehatan Republik Indonesia, 2016). Pemerintah juga menekankan untuk 
menghindari kerumunan dan mencuci tangan secara kontinu.

Hindari adanya kerumunan, berkumpulkumpul karena dapat meyebabkan peningkatan resiko penyebaran yang tinggi. Akan tetapi masih banyak masyarakat yang melanggar dan tidak mematuhi (Natalia et al., 2020). Mencuci tangan merupakan salah satu kegiatan yang wajib dilakukan terlebih selama pandemi COVID-19. Berbagai ahli menyatakan jika rutin mencuci tangan menggunakan sabun pada air yang mengalir adalah salah satu cara yang efektif untuk membasmi kuman ataupun virus. Namun jika kita sedang berasa di luar atau keluar rumah dan ketersediaan air bersih susah, maka hand sanitizer atau cairan antiseptik bisa menjadi alternatif untuk melakukan cuci tangan yang bisa diandalkan.

Handsanitizer adalah salah satu bahan antiseptik berupa gel yang digunakan untuk cuci tangan dimana penggunaan alat ini praktis dan bisa dibawa kemana mana. Bagi sebagian masyarakat mencuci tangan dengan hand sanitizer lebih efektif dan efisien dibanding mencuci tangan dengan menggunakan sabun air. Menurut (Diana, 2012) terdapat dua hand sanitizer yaitu hand sanitizer gel dan hand sanitizer spray. Handsanitizer yang berbntuk gel sebagai salah satu alternatif untuk membersihkan tangan dan menghilangkan kuman dengan yang mengandung allkohol $60 \%$.

Hand sanitizer adalah pembersih tangan berbentuk spray dengan tujuan untuk membersihkan atau menghilangkan kuman yang mengandung bahan aktif yaitu DP 300: $0,1 \%$ dan alkohol 60. Menurut (Fauztihana et al., 2013) menggunakan sabun cair antiseptik lebih efektif daripada hand sanitizer, sehingga penggunaan sabun cair antiseptik lebih disarankan daripada hand sanitizer. Namun jika kondisi sedang di luar rumah maka disarankan dapat menggunakan hand sanitizer, karena hand sanitizer berperan dalam membunuh bakteri atau virus yang melekat di tangan.

PHBS atau Perilaku Hidup Bersih dan Sehat adalah sekumpulan perilaku individu yang dipraktikkan atas dasar kesadaran sebagai hasil pembelajaran yang menjadikan seseorang, keluarga, kelompok atau masyarakat agar mampu menolong dirinya sendiri dalam ruang lingkup Kesehatan masyarakat. Razi dengan koleganya mengatakan bahwa PHBS selama masa pandemik yang bisa dilakukan dalam pencegahan penularan COVID-19 adalah cuci tangan yang baik dan benar, cara menerapkan etika batuk yang benar, physical distancing atau menjaga jarak dan bagaimana cara menjaga kebersihan diri. Kebersihan diri juga dapat terlihat di lingkungan keluarga. Salah satu indikatornya adalah kebersihan rumah. Penerapan dalam bekerja dari rumah dan tinggal di rumah sebagian besar bersifat sukarela sesuai kebutuhan.

Namun, diakibatkan oleh pendemik COVID-19 maka kita diharuskan untuk bekerja dari rumah. Hal ini tentunya memberikan perbedaan yang sangat besar. Beberapa organisasi atau perusahaan mayoritas sudah siap dalam melaksanakan dan membuat skema organisasi/perusahaan dan bagi organisasi/perusahaan yang belum siap maka seirng berjalannya waktu sedikit demi sedikit dapat menyesuaikan.

Sama hanya dengan orang tua yang harus bekera di rumah demi kelangsungan hidup. Orang tua dan anak terpaksa memilih banyak tinggal di rumah karena penaruh pandemik COVID-19. Fenomena yang terjadi saat ini tentunya merubah kondisi yang ada pada sebuah keluarga khususnya dalam menjaga kesehatan dari mulai menerapakan protokol kesehatan yang terdiri dari mencuci tangan yang benar, memakai masker ketika bepergian, menjaga jarak dengan tidak berkerumun dengan komunitas sosial maupun rekan dalam lingkungan. Tentunya dikarenakan keluarga merupakan pusat inti dalam beradaptasi seseorang sebelum keluar rumah (Nur Azizah, 2020).

Pemerintah melakukan banyak berbagai upaya dalam menanggulangi COVID-19 dengan berbagai kebijakan seperti mengurangi aktivitas yang dilakukan di luar rumah mulai dari bekerja menggunakan metode Work Form Home, beribadah di dalam rumah agar penyebaran dapat semakin menurun. Rumah sangat efektif digunakan sebagai salah satu tempat untuk perlindungan namun rumah pun akan sangat efektif apabila dihuni dengan keluarga yang berkualitas, karena kualitas dalam keluarga akan terbentuk apabila keluarga memiliki ketahanan dalam menghadapi segala sesuatu yang menjadi tantangannya (Herdiana, 2020). 


4. KESIMPULAN Wuhan, China. Journal of

1. Sebagian besar perilaku responden selalu menggunakan masker saat keluar rumah, sebanyak $72,6 \%$.

2. Sebagian besar perilaku responden selalu mencuci tangan dengan sabun, sebanyak $47,6 \%$.

3. Sebagian besar perilaku responden selalu menjaga jarak, sebanyak 52,4\%.

4. Sebagian besar perilaku responden selalu menggunakan hand sanitizer, sebanyak $51,2 \%$.

5. Sebagian besar perilaku responden selalu membersihkan rumah, sebanyak $82,1 \%$.

6. Sebagian besar perilaku responden selalu melakukan aktivitas di rumah saja, sebanyak $32,1 \%$.

\section{REFERENCES}

Apriany, D. (2012). Perbedaan perilaku mencuci tangan sebelum dan sesudah diberikan pendidikan kesehatan pada anak usia 4-5 tahun. Jurnal Keperawatan Soedirman, 7 (2). https://doi.org/http://dx.doi.org/10.2088 4/1.jks.2012.7.2.357

Diana, A. (2012). Pengaruh Desiminasi Dokter Kecil Tentang Penggunaan Hand Sanitizer Gel dan Spray Terhadap Penurunan Angka Kuman Tangan Siswa SDN Demakijo Gamping Sleman. Poltekkes Kemenkes Yogyakarta.

Fauztihana, I., Khudayani, R., Qomarkan, M. W., Ariska, E., Widyastuti, P. S., \& Supriyanto, T. (2013). Identifikasi Pusat Pertumbuhan dan Daerah Hinterland Kota Palembang. In Laporan Penelitian. Fakultas Ekonomi, Universitas Sriwijaya.

Herdiana, D. (2020). Penanggulangan COVID-19 Tingkat Lokal Melalui Kebijakan Adaptasi Kebiasaan Baru (AKB) di Provinsi Jawa Barat. Journal of Governance Innovation, 2 (131-156). https://doi.org/https://doi.org/10.36636/j ogiv.v2i2.442

Huang, W.-H., Teng, L.-C., Yeh, T.-K., \& Chen, Y.-J. (2020). 2019 novel coronavirus disease (COVID-19) in Taiwan: Reports of two cases from
Microbiology, Immunology and Infection, 53(3), 481-484. https://doi.org/https://doi.org/10.1016/j.j mii.2020.02.009

Kakodkar, P., Kaka, N., \& Baig, M. N. (2020). A Comprehensive Literature Review on the Clinical Presentation, and Management of the Pandemic Coronavirus Disease 2019 (COVID-19). Cureus, $\quad 12$ https://doi.org/10.7759/cureus.7560

Kementerian Kesehatan Republik Indonesia. (2016). Pedoman umum program Indonesia Sehat dengan pendekatan keluarga. Kementerian Kesehatan Republik Indonesia.

Kimball, A., Hatfield, K. M., Arons, M., \& James, A. (2020). Asymptomatic and Presymptomatic SARS-CoV-2 Infections in Residents of a Long-Term Care Skilled Nursing Facility - King County, Washington, March 2020. Morbidity and Mortality Weekly Report (MMWR), 69 (13), 377-381.

Natalia, R. N., Malinti, E., \& Elon, Y. (2020). Kesiapsiagaan Remaja Dalam Menghadapi Wabah Covid-19. Jurnal Ilmiah Kesehatan Diagnosis, 15.

Nurhalimah, N. (2020). UPAYA BELA NEGARA MELALUI SOSIAL DISTANCING DAN LOCKDOWN UNTUK MENGATASI WABAH COVID-19 (Efforts to Defend the Country Through Social Distancing and Lockdown to Overcome the COVID-19 plague). SSRN.

Singhal, T. (2020). A review of coronavirus disease-2019 (COVID-19). The Indian Journal of Pediatrics, 87(4), 281-286. https://doi.org/10.1007/s12098-02003263-6

Taufiq, M., Nyorong, M., \& Riskiyani, S. (2013). Gambaran Prilaku Hidup Bersih dan Sehat (PHBS) Masyarakat Di Kelurahan Parangloe Kecamatan Tamalanrea Kota Makassar.

WHO. (2020). Report of the WHO-China Joint Mission on Coronavirus Disease 2019 (COVID-19)". 